\title{
Analisa Performansi Photovoltaic 200 WP dan Pompa Air Dc pada Implementasi Sistem Pembangkit Listrik Tenaga Surya (PLTS)
}

\author{
Marshal Jawahar Al Nehru, Bengawan Alfaresi*, Feby Ardianto \\ Program Studi Teknik Elekto, Universitas Muhammadiyah Palembang, \\ Jl. Jenderal Ahmad Yani 13 Ulu Seberang Ulu II, 13 Ulu, Palembang Sumatera Selatan \\ *Correspondence email: begawan_alfarezi@um-palembang.ac.id
}

\begin{abstract}
Abstrak. Air merupakan salah satu produk alam yang paling banyak digunakan oleh manusia seperti untuk kebutuhan keseharian baik untuk minum, memasak, mandi, mencuci dan lain-lain, bahkan industri, pertanian, perkantoran semua membutuhkan air. Air merupakan kebutuhan pokok manusia, namun masih banyak ditemukan pada beberapa daerah dengan sumber mata air terbatas dan sulit dijangkau. Pada penelitian ini bertujuan untuk menganalisa performansi photovoltaic (panel surya) dan hasil pada pompa llistrik pada implementasi system pembangkit listrik tenaga surya (PLTS). Pada penelitian ini merancang pembangkit tenaga surya (PLTS) yang terhubung dengan solar charge Controller dan terhubung langsung pada system pompa air dengan menggunakan baterai sebagai sumber. Berdasarkan hasil penelitian menunjukkan bahwa semakin tinggi radiasi matahari maka output power dari modul PV 200 Wp akan semakin besar sebaliknya semakin kecil radiasi matahari maka output modul PV 200 Wp semakin kecil. Begitu juga terhadap perubahan ketinggian tandon sangat mempengaruhi perubahan debit air dan arus. Semakin tinggi jarak sumur ketandon maka debit air akan semakin kecil dan semakin tinggi jarak sumur ketandon juga berpengaruh terhadap meningkatnya arus.
\end{abstract}

Kata kunci: Pompa Dc; Modul photovoltaic 200 Wp; PLTS, Solar cell

\begin{abstract}
Water is one of the most widely used natural products by humans, such as for daily needs for drinking, cooking, bathing, washing and others, even industry, agriculture, offices all need water. Water is a basic human need, but it is still found in some areas with limited and difficult to reach water sources. This study aims to analyze the performance of photovoltaic (solar panels) and the results of the electric pump in the implementation of a solar power generation system (PLTS). In this study, designing a solar power plant (PLTS) that is connected to a solar charge controller and connected directly to a water pump system using a battery as a source. Based on the results of the study, it shows that the higher the solar radiation, the higher the output power of the 200 Wp PV module. Likewise, changes in reservoir height greatly affect changes in water discharge and currents. The higher the reservoir well distance, the smaller the water discharge and the higher the reservoir well distance also affects the increase in current.
\end{abstract}

Keywords: Dc pump; 200 Wp photo photovoltaic module; PLTS, Solar cell

\section{PENDAHULUAN}

Air merupakan salah satu produk alam yang paling banyak digunakan oleh manusia seperti untuk kebutuhan keseharian baik untuk minum, memasak, mandi, mencuci dan lain-lain,bahkan industry. (Aminuddin, Nurhayati, \& Widiyani, 2019) pertanian, perkantoran semua membutuhkan air. Meskipun air merupakan kebutuhan pokok manusia namun pada beberapa daerah dengan sumber mata air terbatas dan sulit dijangkau, ketersediaan air yang memenuhi syarat menjadi masalah.Meskipun peralatan pompanisasi tersedia, namun bahan bakar minyak atau listrik sebagai tenaga penggerak pompanisasi juga menjadi permasalahan sendiri.

Sistem pompanisasi air pada daerah terpencil dan belum dialiri jalur listrik dari Perusahaan Listrik Negara (PLN) untuk kebutuhan masyarakat sejauh ini banyak digerakkan melalui pengadaan daya listrik yang ditopang oleh sistem dengan basis bahan bakar fosil (Pribadi, 2016). Salah satu Sumber Energi Setempat (SES) yang dimanfaatkan untuk pencatu daya pompanisasi adalah teknologi PembangkitListrik Tenaga Surya (PLTS)
(Widaya, 2012). Pada saat musim penghujan, kinerja PLTS akan berfungsi kurang maksimal, hal ini dikarenakan intensitas cahaya matahari yang rendah dari cuaca yang mendung dan tertutup awan. Beda halnya pada saat musim kemarau tiba, dengan intensitas cahaya matahari yang cukup terik, kinerja dari PLTS tersebut akan memacu secara maksimal (Rahardjo 1, 2014) Pengoperasian PLTS akan berpengaruh dari Intensitas cahaya matahari terhadap besaran energy yang dihasilkan dimana PLTS akan tetap beroperasi walaupun cuaca mendung maupun hujan sekalipun. (Santhiarsa \& Kusuma, 2005). Keuntungan lain dari menggunakan sistem PLTS yaitu tidak memerlukan operator khusus untuk mengoperasikan pompa ini, (Ramadani, 2018) karena sistem ini beroperasi secara otomatis mudah dipasang dan mudah dirawat (Nainggolan, Inaswara, Pratiwi, \& Ramadhan, 2016)

Kinerja panel surya berupa output daya maksimum bervariasi dengan musim. Pada akhir musim panas atau kemarau, kinerja panel surya cenderung meningkat (Napitulu RAM, 2017). Berdasarkan tinjauan kriteria efisien biaya, efektifitas dan ramah lingkungan 
dalam mengurangi emisi $\mathrm{CO} 2$, pilihan terbaik penyediaan energi listrik skala kecil adalah menggunakan panel surya dan dengan catu daya menggunakan panel surya mampu menggerakkan pompa air. (Sinaga R. Tambuhan AH, 2017)

Pompa Air Bertenaga Surya (PABS) mampu beroperasi selama 24 jam sehari. Pada pagi hingga sore hari pompa air menggunakan energi listrik yang dihasilkan oleh panel surya, sekaligus panel surya mengisi baterai. Pada malam hari pompa menggunakan energi listrik dari baterai (Sinaga, 2011). Sistem PABS merupakan teknologi yang paling cocok untuk irigasi pertanian. Kinerja PABS dengan kapasitas yang sama dengan pompa air yang digerakkan secara konvensional memiliki efisiensi yang jauh lebih tinggi. Laju aliran maksimum yang diperoleh PABS adalah 69 liter/menit sedangkan pompa air konvensional adalah 65 liter/menit. (Sinaga R. Prastowo, 2019) Untuk memilih pompa air adalah dengan menentukan debit air aliran pompa, total head dan jumlah kerugian tekanan akibat panjang pipa dan fitting (Satwiko, 2014)

Sel fotovoltaik merupakan suatu rangkaian dioda semikonduktor yang bekerja pada proses khusus yang tidak seimbang (non-equilibrium pocess) dan berdasarkan pada efek fotovoltaik (photovoltaic effect) (Santhiarsa \& Kusuma, 2005). Sel fotovoltaik adalah suatu P-N junction yang berasal dari silikon kristal tunggal. Pada penggunaan photo-electric effect yang terbuat dari dari bahan semikonduktor dapat mengumpulkan radiasi cahaya matahari dan mengkonversi menjadi energi listrik. Energi listrik yang dihasilkan dari Solar PV tersebut berupa arus DC dan dapat langsung digunakan maupun menggunakan baterai sebagai sistem penyimpan sehingga dapat digunakan saat dibutuhkan terutama pada saat malam hari (Aminuddin, Nurhayati, \& Widiyani, 2019)

Karakteristik penting Solar PV yaitu arus hubung singkat (Isc), tegangan open circuit (Voc), efek perubahan temperatur, efek perubahan radiasi matahari, serta karakteristik tegangan-arus pada Solar PV. (Pribadi, 2016) Tegangan open circuit (Voc) yaitu tegangan yang terbaca pada saat arus tidak mengalir atau pada saat arus sama dengan nol. Cara untuk mencapai open circuit (Voc) adalah dengan menghubungkan kutub negatif dan kutub positif pada modul surya dengan voltmeter, sehingga terlihat nilai tegangan open circuit Solar PV pada voltmeter (Gustian, Triyanto, \& Tedy, 2016)

Tujuan penelitian ini untuk menganalisa karakteristik PABS khususnya pada Karakteristik Modul PV $200 \mathrm{Wp}$, analisis efisiensi modul PV $200 \mathrm{Wp}$ dan menganalisa Karakteristik Pompa Air.

\section{METODE}

Penelitian ini dilakukan di Laboratorium Konversi Energi Program Studi Elektro Fakultas Teknik Universitas Muhammadiyah Palembang selama tiga bulan dan implementasi dilaksanakan di Desa pandan Arang Kecamatan kandis, Kabupaten Ogan ilir.

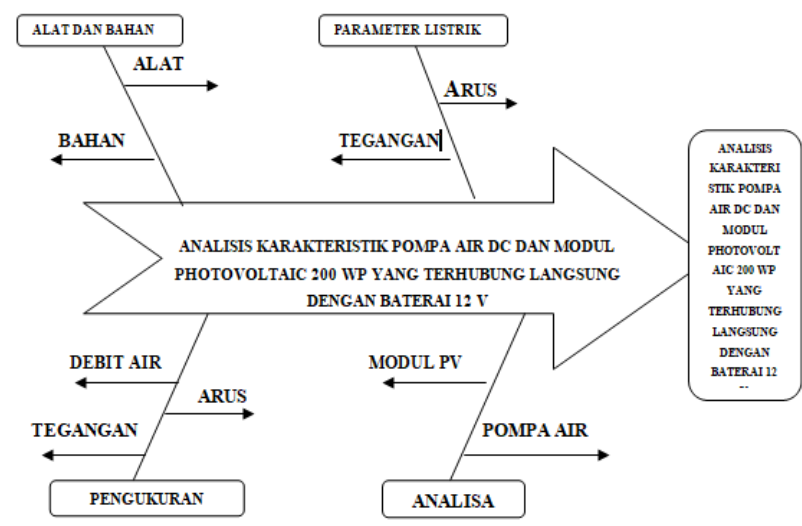

Gambar 1. Diagram Fishbone

Pada Gambar 1 di atas menunjukkan gambar diagram fishbone proses yang dilakukan pada penelitian ini:

1. Penelitian ini diawali mempersiapkan alat dan bahan yang diperlukan untuk proses pengukuran sebelum melakukan pengujian seperti; panel sel surya, solar charge controller, baterai.

2. Pengukuran tegangan dan arus menggunakan multimeter dan debit air yang dihasilkan diukur dengan pengukuran matematik

3. menganalisis karakteristik modul PV dan juga karakteristik Pompa air

\section{Alat dan Bahan}

Adapun beberapa peralatan yang diperlukan dalam penelitian ini adalah sebagai berikut:

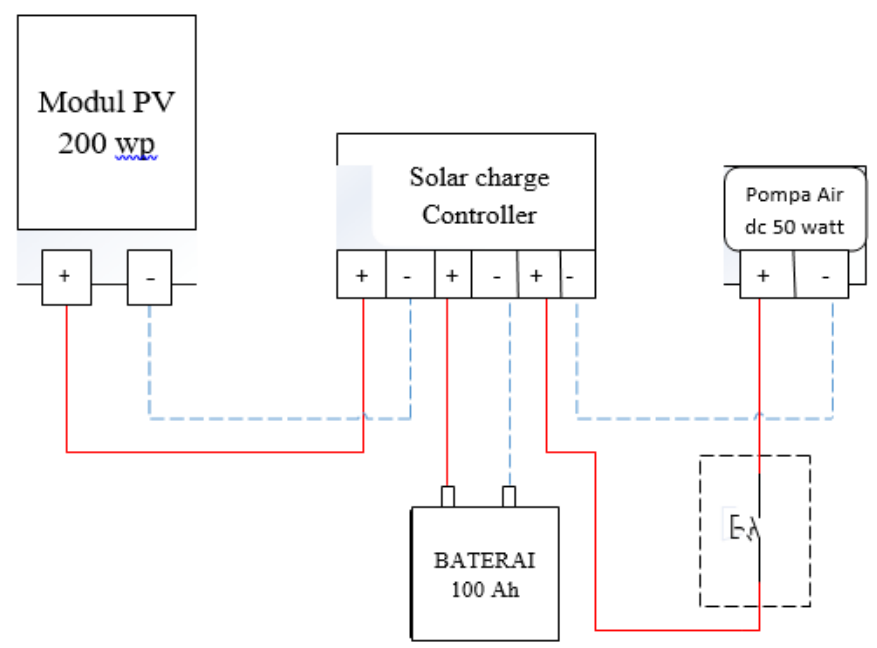

Gambar 2. Diagram block pompa air Tenaga Surya 
Marshal Jawahar Al Nehru et al., Analisa Performansi Photovoltaic 200 WP dan Pompa Air Dc pada Implementasi Sistem Pembangkit Listrik Tenaga Surya (PLTS)

Tabel 1. Alat dan bahan penelitian

\begin{tabular}{|c|c|c|c|}
\hline No. & Jumlah & Karakteristik & Besaran Listrik \\
\hline \multirow{7}{*}{$\begin{array}{l}\text { Panel Sel Surya } 200 \\
\text { Wp }\end{array}$} & \multirow{7}{*}{1} & Optimum Operating Voltage & Vmp $35.9 \mathrm{~V}$ \\
\hline & & Optimum Operating Curent & $\operatorname{Imp} 5,57 \mathrm{~A}$ \\
\hline & & Open Circuit Voltage & Voc $43.7 \mathrm{~V}$ \\
\hline & & Short Circuit Current & Isc $5.91 \mathrm{~A}$ \\
\hline & & Power Tolerance & $0 \sim+3 \%$ \\
\hline & & Weight & $15.8 \mathrm{~kg}$ \\
\hline & & Dimension & $1320 \times 992 \times 35 \mathrm{~mm}$ \\
\hline \multirow[t]{4}{*}{ Baterai } & \multirow[t]{3}{*}{1} & $\begin{array}{l}\text { Tegangan Output } \\
\text { Muatan Listrik }\end{array}$ & $\begin{array}{c}\text { Vout }=12 \mathrm{Vdc} \\
Q=100 \mathrm{AH}\end{array}$ \\
\hline & & $\begin{array}{l}\text { Type Battery } \\
\text { Ty }\end{array}$ & Calcium Premium Battery \\
\hline & & Max PV Voltage & $12 \mathrm{~V}$ \\
\hline & \multirow{4}{*}{1} & Max PV Open Circuit Voltage & $24 \mathrm{~V}$ \\
\hline \multirow[t]{5}{*}{ Solar Charge Controller } & & Mox PV Short Circuit Current & $60 \mathrm{~A}$ \\
\hline & & Max Battery Charge Current & $30 \mathrm{~A}$ \\
\hline & & Nominal Battery Voltage & $12,24 \mathrm{~V}$ \\
\hline & \multirow{5}{*}{1} & Tegangan & $\mathrm{DC} 12 \mathrm{~V}$ \\
\hline & & Ketinggian & 4 meter \\
\hline \multirow[t]{3}{*}{ Pompa Air } & & Daya Pompa & $50 \mathrm{~W}$ \\
\hline & & Diameter Pipa & $1 / 2 \operatorname{Dim}$ \\
\hline & & Kecepatan Putaran & $5800 \mathrm{rpm}$ \\
\hline
\end{tabular}

\section{HASIL DAN PEMBAHASAN}

Hasil pengukuran nilai besaran listrik yang merupakan keluaran dari modul surya ditampilkan dalam bentuk kurva. Tabel. 2 menampilkan hasil pengukuran modul PV 200 Wp. Pengukuran ini dimulai dari pukul 09.00 sampai dengan pukul 15.00 WIB. Untuk pengukuran modul $\mathrm{PV}$ diambil rata-rata hasil pengukurannya sebesar $\mathrm{Voc}=41,97 \mathrm{~V}$, Isc $=4,58 \mathrm{~A}, \mathrm{SR}$ $=917,5 \mathrm{~W} / \mathrm{m}^{2}$. Diketahui luas permukaan solar PV (ASPV) adalah 1,31 m2 maka dapat dicari daya masuk ke panel surya (Pi) seperti persamaan (2.3) . Tabel4.1 menunjukkan hasil pengukuran modul PV 200 Wp yang dilakukan selama 6 jam.

Tabel 2. Hasil pengukuran dan perhitungan pada Modul PV 200 WP

\begin{tabular}{ccccccc}
\hline \multirow{2}{*}{$\begin{array}{c}\text { Pukul } \\
\text { (WIB) }\end{array}$} & \multicolumn{7}{c}{ Solar Pv Monocristalline 200WP } \\
\cline { 2 - 7 } & Voc(V) & Isc(A) & SR(W/m2 & Po(W) & Pi(W) & n(\%) \\
\hline $9: 00$ & 41,11 & 2,94 & 643 & 120,86 & 841 & $14 \%$ \\
$10: 00$ & 41,84 & 4,11 & 765 & 171,96 & 1001 & $17 \%$ \\
$11: 00$ & 42,03 & 4,67 & 947 & 196,81 & 1239 & $16 \%$ \\
$12: 00$ & 42,45 & 5,24 & 1.035 & 222,43 & 1354 & $16 \%$ \\
$13: 00$ & 42,63 & 5,86 & 1.098 & 249,81 & 1437 & $17 \%$ \\
$14: 00$ & 42,43 & 5,11 & 1.027 & 216,81 & 1344 & $16 \%$ \\
$15: 00$ & 42,03 & 4,69 & 960 & 197,12 & 1256 & $16 \%$ \\
16:00 & 41,30 & 4,05 & 865 & 167,26 & 1132 & $14 \%$ \\
Rata-Rata & 41.97 & 4,58 & 917,5 & 192,88 & 1201 & $16 \%$ \\
\hline
\end{tabular}

Tabel 2 di dapat arus maksimum sebesar 5,86 Ampere pada tegangan 42,63 Volt dan radiasi matahari (SR) sebesar $1.098 \mathrm{~W} / \mathrm{m}^{2}$, sedangkan arus minimum sebesar 2,94 Ampere pada tegangan 41,11 Volt dan radiasi matahari sebesar $643 \mathrm{~W} / \mathrm{m}^{2}$. Radiasi matahari sangat berpengaruh terhadap arus listrik. Semakin tinggi radiasi matahari maka arus listrik semakin besar.

Hasil pengujian Pompa Air DC 50 Watt 12 Volt yang disuplai oleh baterai $100 \mathrm{Ah}, 12$ Volt yang telah terisi penuh melalui Modul PV 200 Wp yang dikombinasikan dengan SCC menunjukkan bahwa kemampuan pompa air pada ketinggi $(\mathrm{H})$ 0,5 meter menghasilkan debit air (Q) 600 Ljam, sementara kemampuan tertinggi pompa air ini adalah 3,5 meter dengan debit air maksimum 83LJam. Kemampuan daya pompa air rata-rata adalah 52,46 Watt . Hasil Pengujian Pompa Air DC 50 Watt 12 Volt disajikan pada Tabel 3.

Tabel 3. Hasil Pengujian Pompa Air DC 50 Watt 12 Volt

\begin{tabular}{cccccc}
\hline No. & $\mathrm{H}(\mathrm{m})$ & $\mathrm{Q}(\mathrm{L} / \mathrm{Jam}$ & $\mathrm{Ip}(\mathrm{A})$ & $\mathrm{Vp}(\mathrm{V})$ & $\mathrm{Pp}(\mathrm{Watt})$ \\
\hline 1 & 0,5 & 600 & 5,70 & 9,00 & 51,30 \\
2 & 1,0 & 540 & 5,50 & 8,70 & 47,85 \\
3 & 1,5 & 360 & 4,60 & 7,90 & 36,34 \\
4 & 2,0 & 338 & 6,40 & 8,50 & 54,40 \\
5 & 2,5 & 300 & 6,40 & 8,30 & 53,312 \\
6 & 3,0 & 284 & 6,50 & 9,50 & 61,75 \\
7 & 3,5 & 83 & 6,70 & 9,30 & 62,31 \\
\multicolumn{2}{l}{ Rata-rata } & 358 & 5,97 & 8,74 & 52,46 \\
\hline
\end{tabular}

Arus rata-rata pompa air (Ip) adalah 5,97 Ampere. Dengan menggunakan baterai 100Ah, maka dapat diperkirakan waktu pompa air mampu beroperasi 16,7 Jam saat modul PV tidak bekerja (Radiasi matahari nol).

Tabel 3 Menunjukan bahwa ketinggian tandon berbanding lurus dengan arus yang di hasilkan dimana semakin tinggi tendon semakin besar pula arus yang di hasilkan Arus maksimum ada di ketinggian 3.5 meter yaitu 6.70 ampere dan arus minimum ada pada ketinggian 1.5 meter dengan arus 4.60 ampere.

Ketinggian tandon sangat mempengaruhi debit air. Semakin tinggi jarak sumur ke tandon maka debit air akan semakin kecil dengan trendline linier. Karakteristik debitair terhadap ketinggian tandon dan debit air terbanyak ada di ketinggian 0.5 meter dan debit terkecil ada di ketinggian 3.5 meter

\section{SIMPULAN}

Berdasarkan hasil penelitian menunjukkan bahwa semakin tinggi radiasi matahari maka output power dari modul PV $200 \mathrm{Wp}$ akan semakin besar sebaliknya semakin kecil radiasi matahari maka output modul PV $200 \mathrm{Wp}$ semakin kecil. Begitu juga terhadap perubahan ketinggian tandon sangat mempengaruhi perubahan debit air dan arus. Semakin tinggi jarak sumur ketandon maka debit air akan semakin kecil dan semakin tinggi jarak sumur ketandon juga berpengaruh terhadap meningkatnya arus.

\section{DAFTAR PUSTAKA}

Aminuddin, J., Nurhayati, \& Widiyani, A. (2019). Modifikasi pompa air menggunakan kincir kecepatan rendah sebagai tenaga penggerak. Journal of Islamic Science and Technology, 5 (1).

Gustian, E., Triyanto, D., \& Tedy, R. (2016). SISTEM PENERANGAN RUMAH OTOMATIS BERDASARKAN. Jurnal Coding, Sistem Komputer Untan , 86-96.

Nainggolan, B., Inaswara, F., Pratiwi, G., \& Ramadhan, H. (2016). Rancang Bangun Sepeda Listrik Menggunakan Panel Surya Sebagai Pengisi Baterai. POLITEKNOLOGI, 264-272. 
Marshal Jawahar Al Nehru et al., Analisa Performansi Photovoltaic 200 WP dan Pompa Air Dc pada Implementasi Sistem Pembangkit Listrik Tenaga Surya (PLTS)

Napitulu RAM, S. S. (2017). Pengaruh Material Monokristal dan Polikristal Terhadap Karakteristik Sel Surya 20 Wp dengan Tracking Sistem dua Sumbu. Laporan Penelitian Universitas HKBP Nomensen medan , 45-65.

Pribadi, A. (2016). Pembangkit Listrik Tenaga Surya dengan Rotasi Dinamis. Jurusan Teknik Elektro Fakultas Teknik Universitas Negri Malang , 3443.

Sinaga, R (2011). Pengaruh parameter lingkungan dan penempatan posisi modul terhadap luaran energi PLTS menggunakan solar Cell $50 \mathrm{Wp}, 12$ Volt. Studia Teknologia (SAINTEKS), 178-187.

Rahardjo 1, F. 1. (2014). Analisis Potensi Pembangkit listrik Tenaga Surya di Indonesia. P3TKKE, BPPT , 43-52.

Ramadani, B. (2018). Instalasi Pembangkit Listrik Tenaga Surya Dos \& don'ts. Deutsche Gesellschoft fur Internationale Zusammenarbeit (GIZ) GmbH Energising Develovment (Endev) Indonesia Jakarta , 23-28.

Santhiarsa, G. I., \& Kusuma, G. I. (2005). KAJIAN ENERGI SURYA UNTUK PEMBANGKIT TENAGA LISTRI. Kajian Energi Surya , 29-33.

Satwiko, S. (2014). Uji Karakteristik Sel Surya Pada Sistem Pembangkit Tenaga Hybird. Prosiding Pertemuan Ilmiah XXVI HFI Jateng \& DIY, Purworejo 14 April 2012, 0853-0823.

Sinaga R. Prastowo, S. B. (2019). Analysis of Barriers in Supplying Electricity Using Interpretative Structural Modeling. Energi Strategy Reviews, 11-17.

Sinaga R. Tambuhan AH, S. C. (2017). Analisis Alternatif Solusi Penyediaan Sumber Energi Listrik. Studi Kasus Kabupaten Kupang , 283-290.

Widaya, ,. G. (2012). PEMANFAATAN ENERGI SURYA. JPTK, UNDIKSHA , 9 (1), 37 - 46. 